\title{
The Effect Of Motivation, Leadership And Organizational Culture On Employee Performance In Pt Buana Wirasubur Sakti
}

\author{
Yovie Ernanda*1 Felica Potami ${ }^{2}$, Sakinah Lubis ${ }^{3}$, Yuliani $^{4}$, \\ 1,2,3,4 Universitas Prima Indonesia \\ * Corresponding author: \\ Email : yoviernanda@yahoo.com
}

\begin{abstract}
This study aims to determine the effect of motivation on employee performance at PT. Buana Wirasubur Sakti, to determine the influence of leadership on employee performance at T. Buana Wirasubur Sakti, to determine the influence of organizational culture on employee performance at PT. Buana Wirasubur Sakti, to determine the effect of motivation, leadership and organizational culture on employee performance at pt. the world of wirasubur magic. The population in this study are all employees of PT. Buana Wirasubur Sakti numbered 75 people with a saturated sampling technique using total sampling obtained a research sample of 75 people.

The results showed that partially and simultaneously motivation, leadership and organizational culture had a positive and significant effect on the performance of PT. Buana Wirasubur Sakti. The results of the regression calculation can be seen that the coefficient of determination ( $R$ square) obtained is 0.492 , this result means that $49.2 \%$ of employee performance variables can be explained by motivation, leadership, organizational culture variables, while the remaining 50.8\% is explained by other variables not examined. .
\end{abstract}

Keywords:Motivation, Leadership, Organizational Culture, Performance

\section{INTRODUCTION}

Human resources are one of the most valuable assets owned by a company, because humans are the only resources that can drive other resources [1]. Thus, the element of human resources is a key factor that must be maintained by an organization in line with the demands that are always faced by the company to answer any existing challenges. Therefore, efforts to maintain quality human resources are the main steps of a company.Employee performance is one of the important aspects that the company needs to pay attention to to increase profitability and realize company goals. Performance is the result of work in quality and quantity achieved by an employee in carrying out his duties in accordance with the responsibilities given to him [2]. One of the factors that affect performance is work motivation [3]. Motivation is a factor that encourages someone to do a certain activity, therefore motivation is often interpreted as a factor driving a person's behavior [4]. Every activity carried out by someone must have a factor that drives the activity.

In addition to motivation, leadership factors also support employee performance in a company [5]. In an organization, of course, leaders have different styles or traits in their leadership, where the style describes the character of the leader in interacting and leading the organization [6]. Leadership style is a behavioral norm used by a person when that person tries to influence the behavior of others as he sees it [7].In addition to the leadership style, the company must create an organizational culture within the company to further improve employee performance among fellow employees and to their superiors so that employees are willing and willing to devote their energy and thoughts to work [8]. Organizational culture is the basic philosophy of the organization that contains shared beliefs, norms, and values that are the core characteristics of how to do things in an organization [9]. 
PT. Buana Wirasubur Sakti is a palm oil plantation company based in Indonesia. Based on research conducted at PT. Buana Wirasubur Sakti, researchers found phenomena that occurred at PT. Buana Wirasubur Sakti is related to employee performance. This can be seen in terms of time, there are still employees who have not been able to complete the work on time and procrastinate the work given by the leadership. There are several problems that occur regarding employee performance, one of which is the lack of employee motivation in completing work. This is because employee performance is still not good due to several factors, including employees often get sanctions from superiors, including bosses who like to get angry when employees occasionally do not work as desired by the leadership, so employees feel uncomfortable at work and prefer to stop working. in the company. Should be a good boss can provide input, advice to improve employee performance, so as to create better employee motivation.

Then related to leadership whose application is not appropriate, such as lack of communication and interaction from the leadership to employees. The lack of communication and interaction is caused by leaders rarely monitoring directly on operational activities related to employee work activities. In relation to organizational culture, employees still tend not to take risks for their work, employees and leaders lack attention to company development, employees are less focused on efforts to realize company goals. In relation to organizational culture, problems were found, including the lack of cooperation between employees in completing work, the lack of innovation possessed by employees arising from the incompetence of employees and lack of motivation from the leadership.

\section{METHODS}

This research was conducted at PT. Buana Wirasubur Sakti Medan which is located at J1. M.H Thamrin No.2C, Pandau Hulu I, Kec. Medan Kota, Medan City, North Sumatra 20233 This research was conducted from May 2021 to September 2021. This study used an associative and quantitative approach. The population in this study is limited to employees of PT. Buana Wirasubur Sakti Medan City, totaling 75 people. In this study, the authors used a saturated sample technique, namely determining sampling by taking the entire population as a sample, as many as 50 people. Data collection techniques using questionnaires and data analysis using multiple linear regression analysis.

\section{RESULT AND DISCUSSION}

Table 1. Results of Multiple Linear Regression Analysis and t Test

\begin{tabular}{|c|c|c|c|c|c|c|}
\hline \multirow{2}{*}{\multicolumn{2}{|c|}{ Model }} & \multicolumn{2}{|c|}{$\begin{array}{l}\text { Unstandardized } \\
\text { Coefficients }\end{array}$} & \multirow{2}{*}{$\begin{array}{c}\begin{array}{c}\text { Standardized } \\
\text { Coefficients }\end{array} \\
\text { Beta }\end{array}$} & \multirow[t]{2}{*}{$\mathrm{t}$} & \multirow[t]{2}{*}{ Sig. } \\
\hline & & B & $\begin{array}{c}\text { Std. } \\
\text { Error }\end{array}$ & & & \\
\hline & (Constant) & 9.550 & 5.851 & & 1.632 & .107 \\
\hline \multirow[t]{3}{*}{1} & Motivasi & .357 & .101 & .326 & 3.523 & .001 \\
\hline & Kepemimpinan & .410 & .074 & .509 & 5.558 & .000 \\
\hline & Budaya Organisasi & .006 & .083 & .006 & .075 & .940 \\
\hline
\end{tabular}

The results of multiple linear regression analysis are $\mathrm{Y}=9.550+0.357 \mathrm{X} 1+0.410 \mathrm{X} 2+0.006 \mathrm{X} 3+\mathrm{e}$

1. The explanation of multiple linear regression above is:

2. Constant Value 9,550 means that if there is no or constant then the motivation, leadership and organizational culture variables are 9,550 units.

3. The value of the motivation coefficient of 0.375 is positive, meaning that if the motivation variable is increased by 1 unit, assuming other variables do not change, the employee's performance will increase to 0.375 . 
4. The leadership coefficient value of 0.410 is positive, meaning that if the leadership variable increases by 1 unit, assuming other variables do not change, then employee performance increases to 0.410 .

5. The value of the organizational culture coefficient of 0.006 is positive, meaning that if the organizational culture variable increases by 1 unit, assuming other variables do not change, then employee performance increases to 0.006

While the results of the $t$ test in this study are as follows:

1. The results on the SPSS test the effect of motivation on performance is 3.523>1.993 and obtained a significant value of $0.001<0.05$ which means $\mathrm{Ha}$ is accepted, meaning that the motivation part shows a positive and significant impact on employee performance.

2. The results on the SPSS test the influence of leadership on performance 5.558 $>1.993$ and obtained a significant value of $0.000<0.05$ which means Ha is accepted, namely the leadership section shows a positive and significant impact on employee performance.

3. The results of the SPSS test on the influence of organizational culture on performance $>0.075$ and obtained a significant value of $0.940>0.05$, this means that $\mathrm{Ha}$ is rejected, i.e. the part of organizational culture shows no effect on performance.

Table 2. Results of the Coefficient of Determination

\begin{tabular}{|l|c|r|r|c|}
\hline Model & $\mathrm{R}$ & $\begin{array}{c}\mathrm{R} \\
\text { Square }\end{array}$ & $\begin{array}{r}\text { Adjusted } \\
\text { R Square }\end{array}$ & $\begin{array}{c}\text { Std. Errorof } \\
\text { the Estimate }\end{array}$ \\
\hline 1 & $.702^{\mathrm{a}}$ & .492 & .471 & 2.60278 \\
\hline
\end{tabular}

The results of the regression calculation can be seen that the coefficient of determination ( $\mathrm{R}$ square) obtained is 0.492 , this result means that $49.2 \%$ of employee performance variables can be explained by motivation, leadership, organizational culture variables, while the remaining $50.8 \%$ is explained by other variables not examined.

Table 3. Simultaneous Test (F Test)

\begin{tabular}{|l|l|r|r|r|r|r|}
\hline \multicolumn{2}{|l|}{ Model } & \multicolumn{1}{c|}{$\begin{array}{c}\text { Sum of } \\
\text { Squares }\end{array}$} & df & Mean Square & F & \multirow{2}{*}{ Sig. } \\
\hline & Regression & 466.160 & 3 & 155.387 & 22.937 & \multirow{2}{*}{$.000^{\mathrm{b}}$} \\
\cline { 1 - 5 } 1 & Residual & 480.987 & 71 & 6.774 & & \\
\hline & Total & 947.147 & 74 & & & \\
\hline
\end{tabular}

Based on the table data on the F test above, it can be understood that the Fcount value is $22,937>$ Ftable 2.73 with a significant probability of $0.000<0.05$, so it can be concluded that there is a simultaneous significant effect of motivation, leadership and organizational culture on performance at PT. Buana Wirasubur Sakti.

\section{The Effect of Motivation on Performance}

After going through the entire research process, it can be concluded that the hypothesis proposed at the beginning is declared correct and becomes the main research result that has been submitted to the company. The results of the study indicate that the value of tcount is greater than ttable $(3.523>1.993)$. H1 stated that motivation has a positive and significant effect on the performance of employees of PT. Buana Wirasubur Sakti. Motivation is a factor that encourages someone to do a certain activity, therefore motivation is often interpreted as a factor driving a person's behavior [4]. The relationship between motivation and performance has a linear form, meaning that by providing good work motivation, employee work passion will increase and work results will be optimal in accordance with established performance standards [10][11][12].

\section{The Effect of Leadership on Performance}

Based on the partial test results the influence of leadership on employee performance obtained itung of 
5.558 while $=1.993(5.5581 .993)$ or 0.0000 .05 means being in the rejection area so is rejected ( $\mathrm{Ha}$ accepted), this indicates that leadership has a significant effect on performance employees at PT. Buana Wirasubur Sakti. Leadership is a person's ability to influence others, in this case his subordinates in such a way that other people want to do the will of the leader even though personally it may not be liked by him. [4]. The success of an organization as a whole or various groups in a particular organization, is very dependent on the quality of leadership contained in the organization concerned. In fact, it can be said that the quality of leadership contained in an organization plays a very dominant role in the success of the organization in the performance of its employees [13][14][15][16].

\section{The Influence of Organizational Culture on Performance}

Based on the results of the study, it was obtained that the $t$ count for the organizational culture variable was 0.075 for an error of $5 \%$ for the 2-party test and $\mathrm{dk}=\mathrm{n}-2(75-2=73)$, the $\mathrm{t}$ table was 1.993. If $\mathrm{t}$ count $>\mathrm{t}$ table then there is no significant effect between $\mathrm{X} 3$ and $\mathrm{Y}$, and vice versa if $\mathrm{t}$ count $<\mathrm{t}$ table then there is no significant effect between $\mathrm{X} 3$ and $\mathrm{Y}$, in this case t-count $=0.075>\mathrm{t}$ - table $=0.075$. Buana Wirasubur Sakti. organizational culture can lead to individual satisfaction which is manifested in the form of effective interpersonal meetings and communication, successful individual socialization, and increased work productivity. The purpose of this statement is that Organizational Culture is designed by the company to spur employee performance so that later the company will give awards and the goal is for employees to feel satisfied with their work and the company where they work. So this research is not in line with previous research which states that organizational culture has a positive and significant effect on employee performance [17][18][19].

\section{The Influence of Motivation, Leadership and Organizational Culture on Performance}

Based on the results of the study, it is shown that all the various variables of motivation, leadership and organizational culture have a positive and significant effect on performance. This result is also in line with previous research which states that better motivation, leadership and organizational culture will have an impact on improving employee performance [20][21].

\section{CONCLUSION}

Based on the results of data research and discussion carried out, the following conclusions are obtained:

1. Partially there is an effect of work motivation on employee performance at PT. PT. Buana Wirasubur Sakti.

2. Partially there is an effect of work leadership on employee performance at PT. PT. Buana Wirasubur Sakti.

3. Partially there is no influence of organizational culture on employee performance at PT. PT. World

4. Simultaneously there is an influence of motivation, leadership and organizational culture on employee performance at PT. Buana Wirasubur Sakti.

\section{REFRENCES}

[1] W. H. H. N. M. S. S. H. Ballian, "Analysis of Reward, Work Environment, Job Promotion And Supporting Facilities Towards Job Satisfaction,” Int. J. Innov. Sci. Res. Technol., vol. 5, no. 4, pp. 167-171, 2020.

[2] A. P. A. Mangkunegara, Perencanaan Dan Pengembangan Sumber Daya Manusia. Bandung: PT. Rafika Aditama, 2013.

[3] S. C. S. A. Y. Nasib, "Optimalisasi Prestasi Kerja Melalui Peningkatan Disiplin, Motivasi Dan Lingkungan Kerja Pada PT. Vamrer Jaya Abadi Medan," in The 2nd Interntional Conference on Politics of Islamic Development, 2019, no. April, pp. 192-201.

[4] E. Sutrisno, Manajemen Sumber Daya Manusia. Edisi Pertama. Bandung: Prenada Media Group, 2016.

[5] N. S. Chaniago, "Pengaruh Insentif dan Gaya Kepemimpinan Terhadap Semangat Kerja Karyawan Pada PDAM Tirtanadi Medan," Abdi Ilmu, vol. 1, no. 1, pp. 63-76, 2018. 
[6] Nasib, "Pengaruh Gaya Kepemimpinan Dan Budaya Organisasi Terhadap Kinerja Karyawan Pada PT. Pembangunan Perumahan (Perseroan) Tbk Medan,” Bisman Info, vol. 3, no. 3, pp. 1-12, 2016.

[7] Miftah Thoha, Kepemimpinan Dalam Manajemen. Jakarta: PT. Raja Grafindo Persada, 2013.

[8] A. F. Nasib, Mengenal Dasar Manajemen. Jawa Tengah: CV. Pena Persada, 2020.

[9] Wibowo, Manajemen Kinerja; Cetakan Keempat. Jakarta: PT. Raja Grafindo Persada, 2014.

[10] L. S. K. A. A. N. D. S. A. Rozi, "Pengaruh Motivasi Dan Disiplin Kerja Terhadap Kinerja Pegawai Pada Dinas Pariwisata Purwakarta,” J. Perkusi, vol. 1, no. 1, pp. 101-109, 2020.

[11] I. I. H. K. Had, "Pengaruh Motivasi Dan Lingkungan Kerja Terhadap Kinerja Karyawan,” Manag. J. Ilmu Manaj., vol. 2, no. 3, pp. 1-9, 2020.

[12] Sandhi Fialy Harahap; Satria Tirtayasa, "Pengaruh Motivasi, Disiplin, Dan Kepuasan Kerja Terhadap Kinerja Karyawan Di PT. Angkasa Pura II (Persero) Kantor Cabang Kualanamu,” Maneggio J. Ilm. Magister Manaj., vol. 3, no. 1, pp. 120-135, 2020.

[13] Y. R. S. L. Ratnasari, "Pengaruh Kepemimpinan Dan Motivasi Terhadap Kepuasan Kerja Serta Dampaknya Terhadap Kinerja Karyawan,” Dimensi, vol. 9, no. 3, pp. 505-515, 2020.

[14] D. E. K. R. B. S. I. Gunawan, "Pengaruh Kepemimpinan Pembelajaran, Kepemimpinan Perubahan, Kepemimpinan Spiritual, Budaya Sekolah, dan Etika Profesi terhadap Kinerja Mengajar Guru,” J. Manaj. dan Supervisi Pendidik., vol. 4, no. 3, pp. 198-219, 2020.

[15] L. N. R. N. Ichsan, "Pengaruh Penerapan Kepemimpinan Terhadap Kinerja Pegawai Pada Kantor Dinas Pendidikan Kabupaten Karo,” J. IIm. METADATA, vol. 3, pp. 331-343, 2021.

[16] I. L. Nasib, "Leadership Role Iin The Commitment And Performance of Employees InThe Regional Company Of Medan," Int. J. Innov. Multidiscip. F., vol. 6, no. 8, pp. 58-63, 2020.

[17] Martin, "Job Satisfaction Analysis Through Motivation and Organizational Culture Supervision, Motivation and Organizational Culture,” J. Soc. Sci. Jo Job, vol. 1, no. 3, pp. 66-69, 2020.

[18] nasib; R. Amelia, "Pengaruh Budaya Organisasi Dan Lingkungan Kerja Terhadap Kinerja Karyawan Di PT. Perkebunan Nisantara IV Medan,” in Prosiding Seminar Nasional SINASTEKMAPAN, 2018, vol. I, no. November, pp. 186-197.

[19] M. N. H. A. H. Syam, "Pengaruh Komunikasi dan Budaya Kerja terhadap Kinerja Pegawai,” J. Sustain. Bus. Hub, vol. 1, no. 2, pp. 39-45, 2020.

[20] B. R. M. Maemunah, "Pengaruh Motivasi Kerja, Kepemimpinan dan Budaya Organisasi Terhadap Kepuasan Kerja Karyawan serta Dampaknya pada Kinerja Perusahaan ( Studi kasus pada PT . Concord Indonesia ), J. Manaj. Bisnis Kreat., no. February, pp. 133-157, 2019.

[21] R. S. Y. S. V. F. Sanjaya, "Pengaruh Motivasi , Kepemimpinan, dan Budaya Organisasi terhadap Kinerja Karyawan di Lampung," J. Manaj. Dan Bisnis, vol. 2, no. 2, pp. 251-256, 2020. 